\title{
Diabetestipizálás a mindennapi gyakorlatban: a precíziós diabetológia első lépései
}

Pánczél Pál dr., Lukács Krisztina dr., Hosszúfalusi Nóra dr.

\begin{abstract}
Összefoglalás
A Semmelweis Egyetem III. sz. Belgyógyászati Klinikájának diabetesambulanciájára szigetsejt-specifikus autoantitest (GADA) meghatározásra küldött vérmintákban az antitestvizsgálat mellett meghatározták a vércukor (vc), a C-peptid (Cp) és az inzulin (I) szintjét is, és analizálták, hogy ez javitja-e a cukorbetegség tipizálásának a pontosságát. Két év alatt 207 beteg (124 férfi, 83 nö) vérmintáját vizsgálták. A vércukor, GADA (ELISA), Cp és I (automatizált kemilumineszcens immunoassay) meghatározása a Semmelweis Egyetem laboratóriumaiban történt. A GADA titer, a vc-, a Cp-és I-szint mintázata alapján a TIDM 4 csoportba volt sorolható: TIDM/1-ben a GADA pozitiv, a C $p$ alacsony (a referenciatartomány alatt, <0, 6 $\mathrm{ng} / \mathrm{ml}$ ); TIDM/2-ben a GADA pozitiv, a Cp a normális tartományban van; T1DM/3-ban a GADA negativ, a Cp a 0-hoz közelit. T1DM/4-ben a GADA negativ, a Cp a vércukorszinthez képest viszonylag alacsony. Az exogén inzulint nem kapókban az la $C p$-vel párhuzamosan viselkedett. A GADA titer, a vc-, a Cp-és I-szint mintázata alapján a T2DM 3 csoportba volt sorolható: T2DM/1-ben a GADA negativ, a vc emelkedett, a Cp a normáltartományban, az I a normáltartományban; T2DM/2-ben a GADA negativ, a vc alacsonyabb, a Cp alacsonyabb, az I az exogén inzulin miatt magas; T2DM/3-ban a GADA negativ, a ve magas; a Cp magas, az I magas (inzulinrezisztencia képe). T2DM/1-ben 2 eset alacsony titerü GADA-pozitivitása a kontrollnál negativvá vált (látszólagos álpozitivitás). A mért tényezök egy további 18 tagú csoportban a normális tartományban voltak: e rövid betegségtartamú esetekben valószinüleg a T2DM korai idöszaka állhat fenn. Az anamnézis és az alacsonyabb Cp-szint alapján pancreopriv diabetes gyanúja 3 esetben, MODY lehetösége 2 esetben merült föl. Az elemzett eljárással egy lépésben költséghatékony módon lehet a diabetes tipizálását elvégezni.
\end{abstract}

Kulcsszavak: diabetesklasszifikáció, C-peptid, inzulin, GADA

\section{Classification of diabetes mellitus in the common clinical practice: the first step in precision diabetology}

Summary: The authors performed-beside the GADA determination-blood glucose (BG), serum C-peptide (CP) and insulin (I) measurements in the blood samples sent to GADA analysis to the Diabetes Outpatient Department of the 3rd Department of Medicine Semmelweis University. Blood samples of 207 patients (124 males) were analyzed. The authors evaluated whether the extension of blood tests could improve the diabetes classification. After centrifugation of the samples, the supernatants were surveyed too, and the lipemic sera (4 cases) were analyzed for type I, IV or V hyperlipoproteinemias. The determinations of GADA were made by ELISA; the CP and I were measured by automated chemiluminescent immunoassay. Based on the pattern of GADA titer, the BG-, CP-and concentrations the T1DM could be ranked as follows. TIDM/1: positive GADA, low CP. T1DM/2: positive GADA, CP in the normal range. T1DM/3: negative GADA, CP near to 0.T1DM/4: negative $G A D A, C P$ relative low to the high $B D$. The llevels moved parallel with the $C P$ in patients not treated with insulin. Based on the pattern of GADA titer, the BG-, CP- and I concentrations the T2DM could be ranked as follows. T2DM/1: negative GADA, high $B G$ associated with $C P$ and lin the normal ranges. T2DM/2: negative GADA, lower BG associated with low $C P$ and high llevels (as a result of the insulin treatment). T2DM/3: GADA negative, high BG associated with high CP and I (as a result of insulin resistance). In 18 sera the $B G, C P$ and l levels were in the normal ranges with negative GADA test: in these cases with short disease duration the early stage of T2DM was suggested. Pancreoprive diabetes was suspected in three, MODY 
in two cases based on the anamnesis and low CP levels. This cost-effective method of classification of diabetes seemed to be suitable for the clinical practice.

Key words: diabetes classification, C-peptide, insulin, GADA

DIABETOLOGIA HUNGARICA 25 (№5) 339-346. 2017. október

\section{Röviditések:}

ELISA: enzimhez kötött immunszorbens assay (enzyme-linked immunosorbent assay); GADA: glutaminsav-dekarboxiláz elleni antitest (glutamic acid decarboxylase autoantibody); HLA: humán leukocytaantigén (human leukocyte antigen); LADA: lassan kialakuló 1-es típusú diabetes (latent autoimmune diabetes in adults); MIDD: anyai ágon örökölt, süketséggel társult diabetes (maternaly inherited diabetes and deafness); MODY: monogénes diabetesforma (maturity onset diabetes in the young); PCOS: policisztás ovárium szindróma (polycystic ovarian syndrome); T1-, T2DM: 1-es, 2-es típusú diabetes mellitus (type 1, type 2 diabetes mellitus)

A diabetes mellitus diagnózisa a vércukorszint mérésén alapul, ugyanakkor a cukorbetegség heterogén tünetegyüttes. A vércukorszint a szénhidrátanyagcsere-zavar súlyosságát jelezheti, azonban az etiológiát, a cukorbetegség típusát nem (1. ábra). A megfelelő terápia kiválasztásához azonban ma már szükségessé vált a cukorbaj típusának meghatározása. A cukorbetegség tipizálásához genetikai, immunológiai és béta-sejt-működést jelző vizsgálatokat használhatunk. Jelenleg egyik vizsgálati csoportban sincs valamelyik diabetestípusra kizárólagosan jellemző lelet.

$\mathrm{Az}$ 1-es típusú diabetesre (T1DM) legnagyobb kockázatot jelentő HLA DR3/DR4 genotípus a nem-cukorbeteg populációban sem ritka; a MODY-polimorfizmusok előfordulása pedig az átlagnépességben tízszerese a MODY-betegség előfordulásának. ${ }^{1,2}$

A szigetsejt elleni antitestek bármely formája az átlagnépesség 1\%-ában definíció szerint pozitív lehet. A frissen felfedezett T1DM-es betegek - attól

\begin{tabular}{|c|c|c|c|c|c|}
\hline \multirow[t]{3}{*}{ Stádiumok } & \multirow{3}{*}{$\begin{array}{c}\text { Normoglykaemia } \\
\text { Normális glukózreguláció }\end{array}$} & \multicolumn{4}{|c|}{ Hyperglykaemia } \\
\hline & & \multirow{2}{*}{$\begin{array}{l}\text { Csökkent glukóztolerancia } \\
\text { vagy } \\
\text { Emelkedett éhomi vércukor } \\
\text { (prediabetes) }\end{array}$} & \multicolumn{3}{|c|}{ Diabetes mellitus } \\
\hline & & & $\begin{array}{c}\text { Inzulint } \\
\text { nem igénylő }\end{array}$ & $\begin{array}{l}\text { Inzulin szükséges } \\
\text { az anyagcsere- } \\
\text { kontrollhoz }\end{array}$ & $\begin{array}{l}\text { Inzulin } \\
\text { szükséges } \\
\text { a túléléshez }\end{array}$ \\
\hline \multicolumn{6}{|l|}{ 1-es típus* } \\
\hline \multicolumn{6}{|l|}{ 2-es típus } \\
\hline \multicolumn{6}{|l|}{ Egyéb speciális típusok** } \\
\hline \multicolumn{6}{|l|}{ Gestatiós diabetes } \\
\hline $\begin{array}{l}\text { *T1DM autoimmun/nem autoim } \\
\text { **A A béta-sejt-funkció genetikai er } \\
\text { egyéb eredetű szénhidrátanyag }\end{array}$ & $\begin{array}{l}\text { In eredettel } \\
\text { etű zavara (MODY, MIDD), az inz } \\
\text { ere-zavar }\end{array}$ & hatás genetikai eredetű zavara, az e & crin panci & etegségei, endo & opathiák, \\
\hline
\end{tabular}

\section{1. ábra. A cukorbetegség jelenleg is érvényes kétdimenziós klasszifikációs ábrája}

Az egyik dimenzió a szénhidrátanyagcsere-zavar mértéke, a másik az etiológia, a cukorbetegség típusa. Látható, hogy a glykaemia mértéke alapján a típusra nem vonható le következtetés a nagymértékü átfedés miatt. 
függően, hogy egyidejűleg hányféle antitestet határoznak meg - 2-10\%-a aktuálisan antitestnegatív. ${ }^{1,3}$ A familiárisan T1DM-re kockázatot hordozó, szigetsejt elleni antitestre pozitívak közül számosan nem lesznek cukorbetegek. Külön kérdés a 2-es típusú cukorbetegség (T2DM) klinikai képében megjelenő, szigetsejt elleni antitestre pozitív betegcsoport. ${ }^{1,4}$

A béta-sejt-funkciót jelző paraméterek közül az éhgyomri vagy a terhelésre kialakuló C-peptid-szintek sem specifikusak valamelyik cukorbetegségtípusra. Az éhgyomri C-peptid-szint T1DMben sokáig normális határok között mozoghat. T2DM-ben pedig nincs mindenkinek magas éhgyomri szintje, amely a magas vércukorral együtt az inzulinrezisztenciát jelezhetné. Megjegyzendő, hogy a C-peptid-koncentráció csak a vércukorszinttel együttesen értelmezhető, s értékelésekor az exogén inzulinhatást is figyelembe kell venni. A szérum inzulinkoncentrációja nem megfelelő a béta-sejt-funkció megítélésére, mert a szekretált inzulin a portális vénán keresztül először a májba jut és a májsejtek inzulinreceptoraihoz változó mennyiségben kötődik, csak a nem kötött hormon jut ki a perifériás vérbe. A gyakori mintavételezésű intravénás glukóztolerancia-teszt során észlelhetjük az inzulinszekréció korai fázisának kiesését T1DM kialakulásának korai stádiumaiban, T2DM-ben, LADA-ban, MIDD-ben egyaránt. ${ }^{4,5}$

Tapasztalataink szerint a mindennapi gyakorlatban a szigetsejt elleni antitestek közül a GADA, az aktuális vércukor és a szérum C-peptid-koncentrációja, inzulinkezelés alatt álló betegen a szérum inzulinszintjének együttes értékelése vált be a cukorbetegség típusmeghatározásának segítésére.
Közleményünkben az elmúlt két évben diabetesklasszifikáció céljából a klinikánkra küldött vérminták vizsgálati eredményeit összegeztük és elemeztük, hogy az egyes diabetestípusokban milyen antitest (GADA)/vércukor/C-peptid/inzulin mintázatot találtunk. Értékeltük továbbá, hogy az ilyen módon végzett tipizálás mennyiben segítette a napi betegellátást.

\section{Betegek és módszerek}

Két év alatt 207 beteg tipizálásra küldött, éhgyomorra, reggel levett natív vérét vizsgáltuk. Vércukor-, GADA- (ELISA), C-peptid- és inzulin- (LIAISON C-peptid és LIAISON inzulin automatizált kemilumineszcens immunoassay) meghatározás történt „rutinvizsgálatként” a Semmelweis Egyetem laboratóriumaiban. A LIAISON C-peptid kit leírása szerint a C-peptid-értékek 497 egészséges véradó szérummintájában 0,8-4,2 ng/ml között voltak, ez jelenti a referencia- vagy normáltartományt.

A lipaemiás savókból külön mintát tettünk félre, és 24 órás +4 Celsius-fokon történt tárolás után szemrevételezéssel meghatároztuk a trigliceridben dús lipoproteinek jelenlétét (chylomicron, vagy VLDL, vagy együttesen). Az eredményt konzíliumként, a diabetestípus meghatározásával közöltük, bizonytalanság esetén kontrollt javasoltunk.

\section{Eredmények}

A T1DM-esnek minősített betegeket a vizsgált paraméterek mintázata alapján 4 csoportba oszthattuk (1. táblázat). Az elsőbe tartozók GADA-

1. táblázat. Az 1-es típusú cukorbetegek csoportjainak adatai. A táblázatban az átlagértékek, valamint a legkisebb és legnagyobb érték van megadva

\begin{tabular}{|c|c|c|c|c|c|c|c|c|c|}
\hline Csoport & $\begin{array}{l}\text { Esetszám } \\
(n=96)\end{array}$ & $\begin{array}{l}\text { Férfi/nő } \\
(53 / 43)\end{array}$ & $\begin{array}{l}\text { Kor a kórisme } \\
\text { idején (év) }\end{array}$ & $\begin{array}{c}\text { Diabetestartam } \\
\text { (év) }\end{array}$ & $\begin{array}{c}\text { GADA } \\
\text { (IU/ml) }\end{array}$ & $\begin{array}{l}\text { Vércukor } \\
\text { (mmol/l) }\end{array}$ & $\begin{array}{l}\text { C-peptid } \\
\text { (ng/ml) }\end{array}$ & $\begin{array}{l}\text { Inzulin } \\
(\mu \mathrm{U} / \mathrm{ml})\end{array}$ & $\begin{array}{l}\text { Lipaemiás } \\
\text { savó }\end{array}$ \\
\hline $1 / 1$ & 41 & $17 / 24$ & $\begin{array}{c}41,5 \\
20,0-79,0\end{array}$ & $\begin{array}{c}7,7 \\
0,1-34\end{array}$ & $\begin{array}{c}1284 \\
16-2000\end{array}$ & $\begin{array}{c}10,4 \\
2,8-22,5\end{array}$ & $\begin{array}{c}0,21 \\
0,01-0,56\end{array}$ & $\begin{array}{c}12,8 \\
0,2-108,4\end{array}$ & \\
\hline $1 / 2$ & 36 & $25 / 11$ & $\begin{array}{c}36,4 \\
5,9-62,0\end{array}$ & $\begin{array}{c}1,5 \\
0,1-4\end{array}$ & $\begin{array}{c}944 \\
14-2000\end{array}$ & $\begin{array}{c}9,4 \\
1,3-26,5\end{array}$ & $\begin{array}{c}1,24 \\
0,60-4,80\end{array}$ & $\begin{array}{c}11,9 \\
1,18-64,9\end{array}$ & $\begin{array}{c}1 \times I V-e s \\
\text { típus }\end{array}$ \\
\hline $1 / 3$ & 9 & $3 / 6$ & $\begin{array}{c}38,1 \\
21,0-48,0\end{array}$ & $\begin{array}{c}18,4 \\
1,0-33\end{array}$ & 0 & $\begin{array}{c}14,0 \\
8,7-21,8\end{array}$ & $\begin{array}{c}0,14 \\
0,01-0,44\end{array}$ & $\begin{array}{c}12,0 \\
0,2-35,5\end{array}$ & \\
\hline $1 / 4$ & 10 & $8 / 2$ & $\begin{array}{c}37,4 \\
26,0-43,5\end{array}$ & $\begin{array}{c}3,1 \\
0,1-15\end{array}$ & 0 & $\begin{array}{c}12,9 \\
7,4-20,0\end{array}$ & $\begin{array}{c}0,84 \\
0,54-1,19^{*}\end{array}$ & $\begin{array}{c}7,7 \\
1,4-12,9\end{array}$ & $\begin{array}{c}1 \times V \text {-ös } \\
\text { típus }\end{array}$ \\
\hline
\end{tabular}

*Az 1,19 ng/ml C-peptidhez 20,0 mmol/l vércukor tartozik 
pozitívak, szérumuk C-peptid-szintje $0,6 \mathrm{ng} / \mathrm{ml}$ alatti. A másodikba tartozók GADA-pozitívak és a „normális” határok közötti C-peptid-szekréciójúak. A harmadik csoportot a GADA-negatív és nullához közelítő C-peptid-koncentrációjú betegek alkották, és itt észleltük a leghosszabb betegségtartamot. A negyedik csoportba soroltuk azokat a GADA-negatív eseteket, akikben a C-peptid-szint a vércukor nagyságához képest volt csökkent. A T1DM-es betegcsoport kezelését az említett 4 betegcsoportra lebontva a 2. táblázatban részleteztük.

A klinikum megfigyelése alapján a kezelőorvos, a nem egyértelmű leletek alapján a konzulens javasolt kontrollt. A 2/1 $\rightarrow$ 1/3 áthelyezés egy esetben történt: a beteg kórlefolyásában 2 év alatt a vércukor (mmol/l)/C-peptid $(\mathrm{ng} / \mathrm{ml})$ 7,9/1,8-ről 14,9/0,4-re változott, a GADA maradt negatív. A gyorsan progrediáló inzulinszekréció-csökkenés T1DM-re jellegzetes. Két beteget az 1/4 csoportból az 1/2-be helyeztünk át: egyben a GADA fél év múlva pozitívvá vált, a másikban a 2 évvel korábbi GADA-negativitást váltotta fel az antitestpozitivitás. Ezekben a T1DM-es betegekben a GADA tehát látszólag álnegatív volt.

Kiemeljük, hogy a T2DM-esnek tartott esetek közül kettőben 14 év után, egyben 13 év után igazolódott a T1DM: mindhárman az 1/1 csoportba tartoznak.

Nehezen értékelhető leletegyüttest tapasztaltunk az 1/2 csoportban egy inzulinkezelést nem kapó, metforminterápián lévő betegben: 1,9 $\mathrm{mmol} / 1$ vércukor mellett magas GADA titert (1856 IU/ml), 2,53 ng/ml C-peptidet, 28,42 $\mu \mathrm{U} / \mathrm{m}$ inzulinszintet találtunk. Valószínűleg a T1DM kialakulása során az immunreakció miatt széteső béta-sej- tekből felszabaduló inzulin okozta hypoglykaemiát észlelhettük.

A legidősebb, frissen felfedezett T1DM-es beteg 79 éves volt: GADA $2000 \mathrm{IU} / \mathrm{ml}$, vércukor 2,8 $\mathrm{mmol} / \mathrm{l}$, C-peptid 0,2 ng/ml, inzulin 49,2 $\mu \mathrm{U} / \mathrm{ml}$. Ebben az esetben megfigyelhető, hogy a már elkezdett exogén inzulinkezelés okozta az aktuálisan alacsony vércukorszintet.

OGTT kapcsán küldött anyagból a 0., 60., és 120. percben vett minta C-peptid-szintje 1,38 2,4 - 2,29 ng/ml volt: az emelkedés, azaz az inzulinszekréció korai fázisának csaknem teljes kiesése T1DM-re jellemző lehet, továbbá a 120 perces („késői”) fázisban sem magas az érték, tehát T2DM gyanúja nem merült fel. A C-peptidhez tartozó vércukorértékek 7,8 - 12,2 - 12,3 mmol/1 volt. Mivel a beteg GADA-pozitív volt, az 1/2 csoportba tartozott.

Egy fiatal felnőtt „inzulinos” betegben T2DM lehetősége merült fel. Az esti és a másnap reggeli inzulin kihagyása és tesztétkezés után volt a vérvétel: a vércukor $22,5 \mathrm{mmol} / 1$ lett $0,02 \mathrm{ng} / \mathrm{ml}$ C-peptid- és $0,6 \mu \mathrm{U} / \mathrm{ml}$ inzulinkoncentráció mellett. A ketoacidosis veszélyének elkerülésére általában elég egy éhgyomri minta küldése, a reggeli inzulin beadása elött.

A T2DM-esnek minősített betegeket 3 csoportba oszthattuk (3. táblázat). Az elsőbe soroltuk a GADA-negatív, magas vércukorszintű, megtartott C-peptid-szekréciójú betegeket. A másodikba a GADA-negatív, csökkentnek látszó C-peptid-szekréciójú, de az exogén inzulinadagolás miatt magas inzulinszintű egyéneket. A harmadik csoportot a GADA-negativitás mellett a magas vércukor- és C-peptid-szint együttese által jelzett inzulinrezisztencia jellemezte. A T2DM-es betegcsoport ke-

\section{2. táblázat. A T1DM-es betegek kezelésének adatai}

\begin{tabular}{|c|c|c|c|c|c|}
\hline Csoport & $\begin{array}{c}\text { Azonnal inzulin; } \\
\mathbf{n}(\%)\end{array}$ & $\begin{array}{c}\text { Nem inzulin } \rightarrow \text { inzulin; } \\
\mathbf{n}(\%), \text { év }\end{array}$ & Inzulin nélkül; $\mathbf{n}$ & Nincs adat; $\mathbf{n}(\%)$ & Összes; $\mathbf{n}$ \\
\hline $1 / 1$ & $16(39)$ & $20(48,7), 0,5-6$ & 0 & $5(12,2)$ & 41 \\
\hline $1 / 2$ & $21(58,3)^{* *}$ & $13(36,1), 0,5-5$ & 0 & $2(5,5)$ & 36 \\
\hline $1 / 3$ & $2(22,2)$ & $5(55,5), 2-16$ & 0 & $2(22,2)$ & 9 \\
\hline $1 / 4$ & $7(70)$ & $2(20), 0,5-1,5$ & 0 & $1(10)$ & 10 \\
\hline
\end{tabular}

* n: a kezdetben inzulint nem kapók száma; év: az inzulinkezelés nélküli időszak hosszának legkisebb és legnagyobb értéke

** 3 esetben frissen felfedezett diabetes, tipizálás eredménye alapján való kezelés 
3. táblázat. A 2-es típusú cukorbetegek csoportjainak adatai. A táblázatban az átlagértékek, valamint a legalacsonyabb és legmagasabb érték szerepel

\begin{tabular}{|c|c|c|c|c|c|c|c|c|c|}
\hline Csoport & $\begin{array}{c}n \\
86\end{array}$ & $\begin{array}{c}\text { Férfi/nö } \\
57 / 29\end{array}$ & $\begin{array}{l}\text { Kor a kórisme } \\
\text { idején (év) }\end{array}$ & $\begin{array}{c}\text { Diabetestartam } \\
\text { (év) }\end{array}$ & $\begin{array}{c}\text { GADA } \\
(\text { (IU/ml) }\end{array}$ & $\begin{array}{l}\text { Vércukor } \\
\text { (mmol/l) }\end{array}$ & $\begin{array}{l}\text { C-peptid (ng/ } \\
\text { ml) }\end{array}$ & $\begin{array}{l}\text { Inzulin } \\
(\mu \mathrm{U} / \mathrm{ml})\end{array}$ & $\begin{array}{l}\text { Lipaemiás } \\
\text { savó }\end{array}$ \\
\hline $2 / 1$ & 68 & $46 / 22$ & $\begin{array}{c}40,0 \\
15-63\end{array}$ & $\begin{array}{c}5,8 \\
0,1-31\end{array}$ & 0 & $\begin{array}{c}8,7 \\
3,4-20,3\end{array}$ & $\begin{array}{c}2,25 \\
0,66^{* * *}-5,15\end{array}$ & $\begin{array}{c}23,1 \\
7,5-160,2\end{array}$ & \\
\hline $2 / 2^{*}$ & 14 & $9 / 5$ & $\begin{array}{c}43,3 \\
21-62,9\end{array}$ & $\begin{array}{c}5,5 \\
0,1-13\end{array}$ & $0^{* *}$ & $\begin{array}{c}4,0 \\
0,8-8,6\end{array}$ & $\begin{array}{c}0,56 \\
0,19-0,94\end{array}$ & $\begin{array}{c}37,8 \\
6,74-195,6\end{array}$ & $\begin{array}{l}\text { 1×IV-es } \\
\text { típus }\end{array}$ \\
\hline $2 / 3$ & 4 & $2 / 2$ & $\begin{array}{c}40,5 \\
28-53\end{array}$ & $\begin{array}{c}1,1 \\
2-0,1\end{array}$ & 0 & $\begin{array}{c}15,1 \\
10,1-20,8\end{array}$ & $\begin{array}{c}7,6 \\
5,59-12,4\end{array}$ & $\begin{array}{c}101,4 \\
55,7-170,8\end{array}$ & $\begin{array}{l}1 \times I V-e s \\
\text { típus }\end{array}$ \\
\hline
\end{tabular}

* mindenki inzulinnal kezelt

** 1 eset álpozitív GADA (10 IU/ml)

***31 éves betegségtartam, inzulinkezelés, $11,0 \mathrm{mmol} / \mathrm{I}$ vércukor

4. táblázat. A T2DM-es betegek kezelésének adatai

\begin{tabular}{|c|c|c|c|c|c|}
\hline Csoport & $\begin{array}{c}\text { Azonnal inzulin } \\
\mathbf{n}(\%)\end{array}$ & $\begin{array}{c}\text { Nem inzulin } \rightarrow \text { inzulin;** } \\
\mathbf{n}(\%), \mathbf{e ́ v}\end{array}$ & $\begin{array}{c}\text { Inzulin nélkül;** } \\
\mathbf{n}(\%), \mathbf{v}\end{array}$ & Nincs adat; $\mathbf{n}(\%)$ & Összes; $\mathbf{n}$ \\
\hline $2 / 1$ & $18(26,5)$ & $13(19,1), 1-16$ & $32(47,1), 0,1-16$ & $5(7,4)$ & 68 \\
\hline $2 / 2$ & $5(35,7)$ & $9(64,3), 2-10$ & 0 & 0 & 14 \\
\hline $2 / 3$ & $1(25)$ & 0 & $2(50), 0,1-2$ & $1(25)$ & 4 \\
\hline
\end{tabular}

* n: a kezdetben inzulint nem kapók száma; év: az inzulinkezelés nélküli időszak hosszának legkisebb és legnagyobb értéke

** Az aktuálisan inzulinkezelésben nem részesülők száma és az inzulinkezelés nélkül eltelt időszak legkisebb és legnagyobb értéke

zelését az említett 3 betegcsoportra lebontva a 4 . táblázatban részleteztük.

Látszólag álpozitív GADA is előfordult. Az inzulinkezelésen levő beteg első vérmintájában a GADA $10 \mathrm{IU} / \mathrm{ml}$, a C-peptid 0,64 $\mathrm{ng} / \mathrm{ml}$, a vércukor $2,5 \mathrm{mmol} / \mathrm{l}$ volt. Az alacsony titerü GADApozitivitás mellett a C-peptid csökkenése az inzulinkezelés okozta hypoglykaemiához társulhatott, és inkább T2DM-nek gondolva az esetet, kontrollt javasoltunk. Az 1 év múlva végzett ellenőrző vizs- gálat GADA-negativitást, $4,4 \mathrm{mmol} / 1$ vércukrot, $2,77 \mathrm{ng} / \mathrm{ml}$ C-peptidet talált.

Az esetek 8,7\%-ában a vizsgált paraméterek aktuálisan a normális határok közöttiek voltak és a cukorbetegség típusát illetően nem lehetett következtetést levonni (5. táblázat, 3/1 csoport). A betegek 3,4\%-ában a negatív GADA-teszthez enyhén emelkedett vércukor- és csökkent C-peptid-koncentráció társult: a széles határok között változó életkor a betegség manifesztációja idején, a vál-

5. táblázat. Azon betegek adatai, akikben a vizsgált paraméterek alapján csak annyi mondható, hogy „T1DM nem igazolható" (3/1 csoport), illetve az anamnézis ismerete nélkül nem lehetett következtetni a C-peptid-szint csökkenésének etiológiájára (3/2 csoport). A táblázatban az átlagértékek, valamint a legkisebb és legnagyobb érték szerepel

\begin{tabular}{|c|c|c|c|c|c|c|c|c|}
\hline Csoport & $\begin{array}{c}\text { Esetszám } \\
(\mathbf{n = 2 5})\end{array}$ & $\begin{array}{c}\text { Férfi/nö } \\
(\mathbf{1 4 / 1 1 )}\end{array}$ & $\begin{array}{c}\text { Kor a kórisme } \\
\text { idején (év) }\end{array}$ & $\begin{array}{c}\text { Diabetestartam } \\
\text { (év) }\end{array}$ & $\begin{array}{c}\text { GADA } \\
(\mathbf{I U / m l )}\end{array}$ & $\begin{array}{c}\text { Vércukor } \\
(\mathbf{m m o l} / \mathbf{l})\end{array}$ & $\begin{array}{c}\text { C-peptid (ng/ } \\
\mathbf{m l})\end{array}$ & Inzulin ( $\boldsymbol{\mu U} / \mathbf{m l )}$ \\
\hline $3 / 1$ & 18 & $10 / 8$ & 42,$2 ; 23-75,5$ & 1,$6 ; 0,1-9,0$ & 0 & 5,$11 ; 2,4-7,7$ & 1,$56 ; 1,0-2,77$ & 7,$28 ; 2,87-12,73$ \\
\hline $3 / 2$ & 7 & $4 / 3$ & 34,$2 ; 3-63$ & 10,$4 ; 0,1-33$ & 0 & 8,$8 ; 6,1-13,8$ & 0,$56 ; 0,03-0,95$ & 6,$19 ; 1,36-14,6$ \\
\hline
\end{tabular}


tozó ideig észlelt inzulinkezelés nélküli időszak, a néhányuk anamnézisében szereplő alkoholfogyasztás, hasnyálmirigy-gyulladás alapján ebben a csoportban pancreopriv cukorbetegség és MODY is megbújhat (5. táblázat, 3/2 csoport).

\section{Megbeszélés}

A klinikai gyakorlati szempontokat figyelembe véve az alábbiakat tarthatjuk kiemelésre méltónak.

\section{1/1-1/4 csoport}

A T1DM-es betegcsoportban összességében 40 betegben (41,7\%) 0,5-16 évig csak tablettás kezelés történt. A klasszifikáció itt segítheti legjobban a terápiás döntést. Az irodalmi adatok alapján a LADA-esetekben a sulfanylurea-kezelés különösen káros lehet, elősegítheti a béta-sejt-pusztulás progresszióját. ${ }^{1}$

Az 1/1 csoportból négy, az 1/3 csoportból két beteg tipizálás előtti kórisméje T2DM volt, és $8 \%$ fölötti $\mathrm{HbA}_{1 c}$-szintjük miatt térítéssel kapták az inzulinanalógot. A klasszifikáció igazolta a T1DM fennállását, ezért a továbbiakban „eü. kiemelt” jelzéssel kaphatják azt.

Csak kismértékben javíthatna a tipizálás érzékenységén, ha a GADA mellett több szigetsejt-specifikus antitestet (tirozinfoszfatáz elleni antitest, inzulin elleni autoantitest, cinktranszporter elleni autoantitest) határoznánk meg, mivel a felnőttkorban manifesztálódó T1DM-ben a leggyakoribb a GADA előfordulása. ${ }^{3,4}$ A szigetsejt elleni citoplazmatikus antitest (ICA) indirekt immunfluoreszcenciás meghatározása ma már túlhaladott. ${ }^{1,3,4}$ Itt említjük meg az eredményekben már említett GADA álpozitivitás/álnegativitás kérdését. Egy immunológiai mechanizmussal kialakuló betegség kórlefolyása alatt az antitestkoncentráció a szérumban változhat, az adott módszerrel kimutathatatlanná válhat, tehát nem a teszt hibája („laborhiba”) okozza a jelenséget. Autoantitestek alacsony titerben egészséges populációban is keletkeznek, a mérési eljárás érzékenységét általában úgy állítják be, hogy az ilyen népesség maximum $1 \%$-a lehet pozitív. Tehát az ,álpozitivitás” sem laboratóriumi hiba. Azonban természetesen egy teszt értékelésekor ezeket figyelembe kell venni és a vizsgálatot kérő orvosnak kell a leleteket megfelelően értékelni. Ebbe a kérdéskörbe tartozik, hogy az antitestpozitivitás T1DM-ben változó ideig állhat fenn. Vizsgáltjaink között egy eset 30 éves betegségtartam után is GADA-pozitívnak bizonyult (1/1 csoport).

Ki kell emelni a GDM kérdését. Az 1/1 csoportból három betegnek, az 1/3 csoportból 1 betegnek az anamnézisében szerepelt gestatiós cukorbetegség. A tipizálás eredménye alapján ezekben az esetekben pregestatiós T1DM állhatott fenn. Korábban már magunk is javasoltuk a GDM-es betegek antitestszűrését, most ezt megerősíthetjük. ${ }^{3}$

$\mathrm{Az}$ 1/2 csoportban két esetben igen magas vércukorhoz „normális” C-peptid társult. Egyikük aktuálisan ketoacidotikus volt: valószínűleg nem kell teljes inzulinhiánynak kialakulni ahhoz, hogy ketoacidosis kialakuljon.

Felnőttkori T1DM „honeymoon” periódusában felmerülhet, hogy valóban T1DM áll-e fenn? Egy 37 éves, egy éve kórismézett, inzulinkezelés alatt álló cukorbeteg intenzív életmód-terápiát folytatott. Ismétlődő hypoglykaemiák miatt már csak minimális mennyiségü inzulint kapott. GADApozitív volt (399 IU/ml), a magasabb vércukor $(7,7$ $\mathrm{mmol} / \mathrm{l})$ melletti relatíve csökkent C-peptid (1,33 $\mathrm{ng} / \mathrm{ml}$ ) T1DM-et igazolt.

Az inzulinkezelésre kialakuló jó vércukorszint és szénhidrátanyagcsere-egyensúly mellett az intenzíven diétázó és testmozgást fokozó fiatalban annyira növekedhet az inzulinérzékenység, hogy látszólag „megszűnik” a T1DM.

Ha a C-peptid-szint nullához közelít és nincs egyidejü hypoglykaemia, akkor a GADA-lelet ismerete nélkül is megállapítható a T1DM (természetesen az anamnézisben súlyos pancreasbetegség, pancreas-resectio, pancreatectomia kizárandó). Mivel a C-peptid-vizsgálat naponta történik (ellentétben a GADA-vizsgálat havonta egyszeri végzésével), lehetővé válik a gyors klaszszifikáció, és adott esetben alátámasztható az inzulinkezelés feltétlen szükségessége.

A C-peptid relatíve is lehet alacsony, ami T1DM-et valószínűsít: példaként az egy-egy esetben a $17,1 \mathrm{mmol} / \mathrm{l}$, illetve $15,3 \mathrm{mmol} / \mathrm{l}$ vércukorhoz tartozó 1,00 és 1,08 ng/ml C-peptid hozható fel.

Egy esetben kövér, $102 \mathrm{~kg}, 165 \mathrm{~cm}, 29$ éves korban kezdődött (hétéves betegségtartamú) egyén- 
ben merült föl T2DM gyanúja: a C-peptid már kimutathatatlan, a GADA magas titerben pozitív volt (1/1 csoport). T1DM társulhat „metabolikus szindrómával”, ugyanis a T1DM nem véd a túltáplálkozástól és tespedő életmódtól.

\section{A 2/1-2/3 csoport}

Két betegben észleltünk a felfedezéskor ketonuriával járó T2DM-et. ${ }^{6}$ Az 54 éves betegben 22,8 mmol/l vércukorral, ketonuriával manifesztálódott a betegség. A később küldött mintában a GADA negatívnak, a vércukor 5,4 mmol/l-nek, a C-peptid 1,1 ng/ml-nek, az inzulin 10,8 $\mu \mathrm{U} / \mathrm{ml}$-nek bizonyult. A 62 éves beteg felfedezésekor a vércukor $31,4 \mathrm{mmol} / 1$ volt, és ketonuria is igazolódott. A később tipizálásra küldött vérmintában a leletek az alábbiak voltak: GADA negatív, vércukor 3,2 $\mathrm{mmol} / \mathrm{l}, \mathrm{C}$-peptid $1,77 \mathrm{ng} / \mathrm{ml}$, inzulin $12,8 \mu \mathrm{U} / \mathrm{ml}$.

A diabetes tipizálása segíthet abban, hogy az adott eset manifesztálódásakor a megfelelő indikációval elkezdett inzulinkezelés folytatásáról vagy más kezelésre való átállításáról dönthessünk, azaz feleslegesen ne „maradjon rajta az inzulinon” a T2DM-es beteg. Példaként mutatjuk be a 2/1 csoport egyik betegét. Más intézetben frissen felfedezve: vércukor $16,7 \mathrm{mmol} / \mathrm{l}, \mathrm{HbA}_{1 \mathrm{c}} 16,1 \%$, ketonuriára nincs adat. Intenzív konzervatív inzulinkezelés + metformin kezdődött. Két hónap múlva hypoglykaemiák és hízás miatt vizsgáltuk: vércukor $5,8 \mathrm{mmol} / \mathrm{l}, \mathrm{HbA}_{1 \mathrm{c}} 10,2 \%$, GADA negatív, C-peptid 2,13 ng/ml, inzulin 16,62 $\mu \mathrm{U} / \mathrm{ml}$. Az inzulint elhagytuk, gastrointestinalis intolerancia miatt a metformint a beteg hagyta el. Újabb 3 hónap múlva: vércukor 7,5 mmol/1, $\mathrm{HbA}_{1 \mathrm{c}} 7,0 \%$, C-peptid $2,73 \mathrm{ng} / \mathrm{ml}$. Testsúlya $1 \mathrm{~kg}$-ot mérséklődött, az életmód-terápiát folytattuk.

Az exogén inzulin is visszaszoríthatja a saját inzulintermelést, ami a C-peptid alacsony szintjében nyilvánul meg: ez viszonylag gyakori észlelet. GADA-negativitás esetén kontroll célszerü: egy esetben a kontrollnál is hypoglykaemia + alacsony C-peptid-, magas inzulinszint volt $\rightarrow$ harmadik kontroll is kell.

Egy PCOS-es + T2DM-es betegben a magas C-peptid- és inzulinszint $(12,4 \mathrm{ng} / \mathrm{ml}$ és 77,69 $\mu \mathrm{U} / \mathrm{ml}) 10,1 \mathrm{mmol} / \mathrm{l}$ aktuális vércukor mellett jelezte az inzulinrezisztenciát. Öt T2DM-es beteg anamnézisében szerepelt GDM (5,8\%).

\section{A 3/1-3/2 csoport}

A 3/1 csoportban a negatív GADA- és a „normális" vércukor-, C-peptid- és inzulinleletekre tekintettel pusztán a küldött vérminta vizsgálata alapján biztos következtetést csak annyiban lehetett levonni, hogy T1DM aktuálisan nem igazolható. Ez az esetek 8,7\%-a volt.

A 3/2 csoportban a fó jellegzetesség a negatív GADA mellett az alacsony, de meglevő C-peptid-szekréció. Négy beteg anamnézisében előrement hasnyálmirigy-betegség szerepelt. Három esetben merülhetett föl a MODY a mérsékelten csökkent C-peptid-szint alapján: 0,48 és $0,95 \mathrm{ng} / \mathrm{ml}$ közötti értékekkel. Az anamnézis értékelése a kezelőorvos által ebben a csoportban elengedhetetlen.

\section{Következtetések}

1. A fenotípus alapján nem határozható meg a cukorbetegség típusa.

2. Az elemzett tipizálási eljárás költséghatékonynak tűnik: a GADA + C-peptid + inzulin meghatározás összköltsége jelenleg 5097 laboratóriumi pont (összehasonlításként: a $\mathrm{HbA}_{1 \mathrm{c}}$-vizsgálat ára 1100 pont).

3. Segíti a napi gyakorlatot: eredmény 2-3 héten belül várható (de ha a C-peptid-lelet, amely naponta mért paraméter, kórjelző, azonnal küldhető az eredmény).

4. Az eljárás segíti a személyre szabott kezelést:

- Ha T2DM helyett LADA igazolódik, sulfanylurea kontraindikált, helyette inkretinalapú (DPP-4-gátló, GLP-1-receptoragonista) terápia vagy inzulin adása célszerü. ${ }^{1}$

- Ha magas vércukrot magas C-peptid-szint kísér, nem biztos, hogy inzulin vagy sulfanylurea a célszerű terápia.

- Ketonuriával (ketoacidosissal?) manifesztálódó felnőttkori cukorbetegségben segíti a későbbi döntést az inzulinkezelés folytatásáról.

- MODY típusú diabetes gyanúját veti fel a GADA-negativitás, a megtartott C-peptid-szint (>0,6 $\mathrm{ng} / \mathrm{ml})$ és a klinikai adatok: a genetikai vizsgálat a terápia megválasz- 
tása szempontjából nem sürgető (kivéve a KCNJ11/ABCC8 génmutáció által okozott neonatális diabetest, amely sulfanylureára jól reagál).

- A mitokondriális génmutáció által okozott, anyai ágú öröklődésű MIDD fő gyanújele a kizárt T1DM mellett a sensorineuralis nagyothallás: számítani kell a gyors progresszióra és az inzulindependencia kialakulására. A genetikai vizsgálat hazánkban is rendelkezésre áll. ${ }^{5}$

5. A betegnek elmagyarázva és megbeszélve a leleteket, bevonhatjuk a terápiás döntésbe, és tudatosíthatjuk a részvételét a kezelésben. „4Pmedicine: precision, predictive, preventative, participatory".

6. A cukorbetegség klasszifikációjában elért haladás során megfigyelhettük, ahogy a „tudomány" átalakult a napi gyakorlattá.

7. Az EASD hivatalos lapjának 2017. májusi számában megjelent szerkesztőségi közleményben olvashatjuk: „A precíziós medicina új világának első lépéseként a diabetológusok kezdjék el rutinszerűen használni a jelenleg is rendelkezésre álló eszközöket: autoantitest- és C-peptid-mérést talán mindenkinél, genetikai teszteket egynéhánynál, hogy véglegesebb kórisméket állíthassanak fel."

\section{Irodalom}

1. Leslie RD, Palmer J, Schloot NC, Lernmark A: Diabetes at the crossroads: relevance of disease classification to pathophysiology and treatment. Diabetologia 2016; 59: 13-20. doi:10.1007/s00125-015-3789-z

2. Flannick J, Beer NL, Bick AG, Agarwala V, Molnes J, Gupta N, et al: Assessing the phenotypic effects in the general population of rare variants in genes for a dominant mendelian form of diabetes. Nat Genet 2013; 45: 1380-1385. doi: $10.1038 / \mathrm{ng} .2794$

3. Pánczél P, Külkey O, Luczay A, Bornemisza B, Illyés G, Halmos $T$, et al.: Hasnyálmirigy-szigetsejt elleni antitestek vizsgálata a klinikai gyakorlatban. Orvosi Hetilap 1999; 140: 2695-2701.

4. Pánczél P, Hosszúfalusi N: A felnőttkori látens autoimmun diabetes (LADA). Orvosképzés 2010; 85: 115-119.

5. Pánczél P, Hosszúfalusi N: Mitokondriális génmutációhoz t (A3243G) társuló diabetes mellitus. Az első két magyarországi család leirás. Orvosképzés 2010; 85: 175-181.

6. Palik E, Hosszufalusi N, Vatay A, Karadi I, Romics L, Panczel P: Idiopathic Type 1 or ketosis prone Type 2 diabetes? Diabetologia 2004; 47: 302.

7. Marshall SM: Precision diabetes: a realistic outlook on a promising approach. Diabetologia 2017; 60: 766-768. doi:10.1007/s00125-017-4244-0

Közlésre érkezett: 2017 . június 19.

Közlésre elfogadva: 2017. augusztus 8.

\section{A levelezésért felelős szerző}

\section{Dr. Pánczél Pál}

Semmelweis Egyetem ÁOK, III. Belgyógyászati

Klinika

1125 Budapest, XII. Kútvölgyi út 4.

E-mail: panczelp@yahoo.com 